\title{
Deconstruction, Literature, and Wittgenstein's Privileging of Showing
}

\author{
Alex Segal* \\ School of Humanities and Social Sciences, Charles Sturt University, Australia \\ Corresponding Author: Alex Segal, E-mail: asegal@csu.edu.au
}

\section{ARTICLE INFO}

\section{Article history}

Received: September 16, 2017

Accepted: November 20, 2017

Published: December 30, 2017

Volume: 8 Issue: 6

Advance access: December 2017

Conflicts of interest: None

Funding: None

\begin{abstract}
Wittgenstein's distinction between saying and showing involves a privileging of the latter. This privileging, which is both ethical and aesthetic, emerges in Wittgenstein's attitudes to literature. Involving the metaphysics of presence and an oppositional hierarchy, it seems to be a possible target of Derrida's deconstruction. Indeed, in Wittgenstein, Derrida sees an effacement of theory, an effacement that Derrida criticises and that can be construed as part and parcel of Wittgenstein's privileging of showing. For theory belongs to saying rather than to showing. Focusing on commentators of Wittgenstein who affirm the privileging of showing, this essay explores a tension between Wittgenstein and Derrida that pertains to this privileging.
\end{abstract}

Key words:

Literature,

Ethics,

Showing,

Saying,

Theory,

Humility,

Self-recognition

\section{INTRODUCTION}

Several philosophers and literary theorists have drawn on Ludwig Wittgenstein's philosophy, particularly his latter philosophy, in order to criticise the deconstruction of Jacques Derrida. Henry Pickford for example sees in Wittgenstein "a powerful rebuttal to deconstructive arguments for meaning scepticism" (Pickford, 2016 Kindle Locations 109-110), and he mentions other Wittgensteinian critiques of Derrida (John Gibson, Fiction and the Weave of Life, 2007; Michael Fischer, Stanley Cavell and Literary Skepticism, 1989). Less common perhaps is drawing on Derrida to critique Wittgenstein; Christopher Norris's The Deconstructive Turn is an early instance of this. It is the possibility of such a critique that I wish to broach here, focussing in particular on Wittgenstein's distinction between showing and saying - and on the way that at issue in this distinction are questions to do with value, including to do with literature. My focus will be at least as much on commentators sympathetic to Wittgenstein as on Wittgenstein himself. I will approach the issue in the following way.

In Section 1, I articulate and clarify some aspects of Wittgenstein's privileging of showing over saying, high- lighting how this privileging seems to be called into question by certain aspects of Derrida's thought and how its tensions lend plausibility to Derrida's position. In Section 2, I argue that comments of Wittgenstein scholars that might seem to enable a response to the Derridean critique do not really succeed in this. In Section 3, I argue - with reference to Tolstoy's story "The Three Hermits" - that the appeal to literature (or at least to a certain kind of literature) may not offer the kind of support for the privileging of showing that some scholars think it does. The three sections work together to suggest that Derrida's work enables us to recognise a limitation, a blind spot in Wittgenstein's. At issue is a deepening of our understanding of the relationship between Wittgenstein and Derrida, two of the greatest twentieth-century philosophers.

Articulated most famously in the early Tractatus (1922) but arguably informing Wittgenstein's work more generally, the showing/saying distinction is linked to questions of value - questions to do with aesthetics, ethics and religion. Given that Wittgenstein ties propositions to saying, his linking of showing to value seems to emerge in statements from the Tractatus - "there can be no ethical propositions"; "propositions cannot express anything higher"; "ethics and aesthetics 
are one" (Wittgenstein, 1922, p. 56, 6.42; 6.421) - and from his statement (in a letter to Bertrand Russell) about the Tractatus: "The main point is the theory of what can be expressed [gesagt] by props - i.e. by language - (and which comes to the same, what can be thought) and what cannot be expressed by props, but only shown [gezeigt]" (Wittgenstein, 1974, p. 71).

Wittgenstein's affirmation of showing is often noted. Philip Shields argues that for Wittgenstein, "the possibility of saying is always dependent on a kind of showing,... on a prior existence of logical form or logical grammar"; we are "ultimately dependent on pre-established conditions that lie forever beyond our personal control", conditions that "show themselves", that "lie before us like the will of God" (Shields, 1993, p. 56). Bob Plant argues that for Wittgenstein, religious beliefs are "rooted in the practical-ethical lives of those professing them"; with respect to the question about God's existence, genuine believers "can only adequately respond by "showing' us that orientation" - "the orientation of their life as a whole" (Plant, 2004, p. 460). Referring to various post-Tractatus texts, David Cooper argues that Wittgenstein viewed with wonder the "inexpressible" or unsayable fitting together of language (or thought) and world that forms the background against which we speak (Cooper, 1997, p. 113).

And the affirmation of showing informs Wittgenstein's attitude to particular literary works. In 1945 - with Hadji Murad in mind - he wrote: "when Tolstoy just tells a story he impresses me infinitely more than when he addresses the reader. When he turns his back to the reader then he seems to me most impressive.... his philosophy is most true when it's latent in the story" (Malcolm, 2001, p. 38). Brian McGuinness says that Hadji Murad's nobility "shines through the misfortunes"; it can only be seen "from the style"; "only be shown, not said" (McGuinness, 1988, p. 33). James Conant points out that Hadji Murad contains "virtually no ethical vocabulary" (Conant, 2005, p. 100). And citing Wittgenstein's saying of a poem he admired (Ludwig Uhland's Graf Eberhards Weissdorn) that "If only you do not try to utter the unutterable then nothing gets lost" (Engelmann, 1968, p. 7), Conant argues that for Wittgenstein "the ethical is contained in what is uttered without itself ever being that which is said.... it figures in. non-overtly ethical utterances" (Conant, 2005 , p. 67). In arguing that Wittgenstein affirms "realism in philosophy", Cora Diamond refers to the way that in realist novels and stories we find not "lots of sentences like 'Like all Russian officials, he had a weakness for cards" ", but "certain kinds of attention to reality: to detail and particularity": "The weakness for cards of a character in a realistic novel may be shown us, but it will be shown as it is in him, and will not simply be a deduction.... character ... is built up out of observed detail, and in a sense there is nothing to it over and above what we are shown" (Diamond, 1991, p. 40)i

With respect to ethics, some see convergence between Wittgenstein and Derrida. Susanna Lindroos-Hovinheimo argues that for both, language presupposes "a kind of welcome or saying 'yes' to another person" (Lindroos-Hovinheimo, 2012, p. 98) - and this welcome, this saying "yes" seems not to be a matter of the kind of saying that is tied to propositions, the kind of saying that Wittgenstein subordinates to showing. Henry Staten argues that both deny that a "mental act of meaning" makes "the difference between full speech and citation", and thus perhaps suggests (and perhaps not all that plausibly) that Wittgenstein shares Derrida's doubt "about an idealized picture of sincerity that takes insufficient account of the windings and twistings of fear and desire, weakness and lust, sadism and masochism and the will to power, in the mind of even the most sincere man" (Staten, 1984, pp. 126-127). Moreover, Derrida, like Wittgenstein, seems to contrast ethics and saying - at least in a certain way. He argues that "one cannot speak directly about justice, thematize or objectivize justice, say 'this is just' and even less 'I am just', without immediately betraying justice" (Derrida, 1992a, p. 10); that a gift is no longer a gift, is annulled, if it is recognised as gift. Such recognition gives back "in the place, let us say, of the thing itself, a symbolic equivalent" (Derrida, 1992b, p. 13), a giving back, a return, which reduces the gift to an exchange. Therefore, one cannot say "This is a gift" or "I have made someone a gift". Wittgenstein may seem to express a similar attitude when he writes: "If you offer a sacrifice and are pleased with yourself about it, both you and your sacrifice will be cursed" (Wittgenstein, 1980 , p. 26). This perhaps comes close to saying that if you are pleased with your sacrifice, you get a return on your sacrifice, which thereby ceases to be a sacrifice

But a divergence seems also to be issue. In arguing that saying annuls the gift, Derrida is not excluding saying from the realm of value altogether; so it is not a problem that his argument is itself an instance of saying. Derrida disparages a belief in effacing "the labor of theory" from literature (Bennington \& Derrida, 1999, pp. 62-63) which he associates with Wittgenstein, which seems part and parcel of Wittgenstein's privileging of showing over saying, given that theory belongs to saying. Derrida connects the naivety of Proust's attempt to efface this labour (in the statement "A work in which there are theories is like an object which still has its price-tag on it" (Proust, 2000, p. 236)) to the way that such labour marks Proust's literary text - a marking that Derrida does not criticise. So although Derrida may reject reducing the literary work to saying, this for him is not an effacement of saying from the work. And inasmuch as Derrida does displace saying, this is not in order to privilege showing. For, as we have in effect seen, he argues that if the gift presents itself as gift (a presentation which would seem to be a matter of showing), then the gift is recognised as gift - which entails a return on the gift; and so no gift. Thus for Derrida the gift not only cannot be said; it cannot be shown either.

The plausibility of the Derridean position is perhaps suggested by a possible blindspot in the way that the Wittgensteinian moral philosopher Raimund Gaita privileges showing over saying. Gaita writes that the "deepest values of the life of the mind cannot be taught: they can only be shown"; "teachers inspire their students into a proper love of what they are doing by the manner of their attention to their subject" (Gaita, 1999, p. 231) - attention which is shown rather than said. The showing that Gaita affirms is tied to rec- 
ognition - and to self-recognition. He argues that the deepest values are revealed to us in lucid and genuine remorse, which he describes as "a recognition of the reality of another through the shock of wronging them" (Gaita, 1991, p. 52), a recognition tied to self-recognition: in remorse, "the meaning of what one has done, what one has become through doing it, and what one's victims have suffered, are inseparable" (Gaita, 1999, p. 34); "the self ... discovers itself" (Gaita, 1991, p. 79). Now Gaita also argues that goodness in another elicits a wonder that focuses not on the good person - in a sense, she "disappears from consideration" (Gaita, 1991, p. 206) - but on what her goodness reveals: for example (not just one among others), the otherwise invisible humanity of the profoundly afflicted. He evokes a disappearance from consideration, a self-effacement perhaps, not merely of the good person but also of her goodness. For he affirms the notion - Christian, perhaps Platonic, yet also commonplace - that a deed done for "the sake of being or doing good", done "because of an appreciation of its Goodness", cannot be good (Gaita, 1991, pp. 89-90), a notion implying that in doing a good deed, one cannot anticipate appreciation of its goodness by another. Referring to Plato, Gaita asks "how can justice ... be said to be good to its possessor if, ex hypothesi, it is invisible ('deprived of all seeming'), if there is no internal connection between, as it were, the virtue of a virtue and its being visible to the appreciative judgement of one's peers?" (Gaita, 1991, p. 97). If goodness is thus invisible, it cannot be shown. So the privileging of showing seems to come undone.

And there may also be a tension in the position that Bob Plant ascribes to Wittgenstein. Plant argues that Wittgenstein posits a severing - tied to humanity's feeling of wretchedness - of "responsibility (the ethical 'ought')" from "possibility (the ontological 'can')": "when God commands me this does not necessarily entail the possibility of my being able to fulfil that injunction. God's commandments come from a certain moral 'height' outside the customary rules governing ethical discourse and human responsibility" (Plant, 2004, p. 467). Now we have also seen that Plant ascribes to Wittgenstein) the notion that genuine believers can truly show us the orientation - of their life as a whole" - that confirms their belief (Plant, 2004, p. 460). Yet showing this perhaps implies seeing one's life as fulfilling commandments the 'height' of which means that they cannot be fulfilled.

A few commentators on Wittgenstein have tried to address the difficulties for the privileging of showing that are emerging here. To their work I now turn.

Citing Wittgenstein's statement "Self-recognition \& humility is one" (Wittgenstein, 2003, p. 105), David LaRocca argues that although Wittgenstein saw that self-recognition "can contribute to one's vanity", he saw also that it enabled one to "recognize how one's vanity is compromising". The self-recognition that Wittgenstein values is, says LaRocca, a humbling "will-based" "disciplined habit of determining one's qualities and lapses", a habit which, being associated with action, would seem to involve showing rather than saying. It contrasts with a narcissistic, self-involved self-knowledge, which, being "intellect-based", would seem to be tied to propositions, to saying. If humility requires a concrete determining of one's lapses, and if this requires determining one's qualities in general, then determining one's virtues (which are among one's qualities) is compatible with and may even be required by humility. The virtues can show themselves (LaRocca, 2013, p. 325).

Another Wittgensteinian, Stephen Mulhall describes a way that the virtues resist presenting themselves fully: Someone satisfies the standards at issue by recognising that they are "indefinitely perfectible (without ever reaching a state of perfection)". Socrates' wisdom involves his "knowing how unwise he actually is"; awareness of her failure "to live up to the ideals of parenting" confirms a parent's "exemplary status". But Mulhall argues that God exemplifies virtue "beyond any possibility of criticism" (Mulhall, 2016, pp. 82-83). God's perfect wisdom presents itself to Him fully; fully shows itself. So for Mulhall, there is no radical breach in showing. In contending that a perfection term used of God is apophatic, non-literal, he does not testify to the non-presence that for Derrida should mark any evocation of God, no matter how non-literal.

Michael Kremer - in a passage cited sympathetically by Kevin Cahill (Cahill, 2011, p. 84) - also links recognition of one's virtues to Wittgensteinian humility: "True humility. is a gift of God's grace that recognizes itself as such; the truly humble person is the one whose gratitude to God encompasses and includes her own humility" (Kremer, 2001, p. 49). My humility being a gift of God, not my own, I can recognise it without narcissism, without a humility-annulling pride in it. So Wittgenstein, on Kremer's picture, rejects Derrida's view that gratitude for the gift of humility annuls humility and reduces the gift to an exchange.

I would have liked to see Derrida engage more explicitly with putatively Wittgensteinian takes on the idea that humility can embrace recognition of one's own humility. But the just-cited accounts seem rather inadequate. In the first place they seem at odds with Wittgenstein's statement that "Self-recognition \& humility is one" - a philosophical statement about humility in general. Kremer's tying humility to the recognition of one's humility seems not to embrace the purest instance of humility. For God's humility (embodied for Christians in Jesus) seems to be God's own, not a gift to him. It is true that Jesus' humility may to some extent be tied to his bearing the burden of the human condition - in which one's virtues are a gift from another: St Paul says that Jesus humbled himself, "being found in human form" (Philippians 2:8). But before saying this, St Paul says that Jesus, "though he was in the form of God, did not regard equality with God as something to be exploited, but emptied himself, taking the form of a slave, being born in human likeness" (Philippians $2: 7)$. This pictures the emptying of self, the humility, that is involved in taking the form of a slave as anteceding Jesus being found in human form. Such humility seems not to be a gift from an other - at least, not in the way that human humility may be thought to be such a gift. To show that humility is compatible with self-recognition, Mulhall emphasises the inevitable imperfection of the virtues of humans and LaRocca emphasises recognition of one's lapses. But neither suc- 
ceeds thereby in tying the self-presence of God to humility. For God's virtues are perfect; and He does not have lapses.

Moreover, I think that LaRocca, Mulhall and Kremer insufficiently acknowledge the denegation of recognising one's own virtues that is found in Christianity - in, for example, Matthew 6: "When you give alms, let not your left hand know what your right hand does"; in C. S. Lewis's statement that "a man is not usually called upon to have an opinion of his own talents at all, since he can very well go on improving them to the best of his ability without deciding on his own precise niche in the temple of Fame" (Lewis, 1996, p. 302); and perhaps in Simone Weil's contentions that: "Compassion and gratitude come down from God, and when they are exchanged in a glance, God is present at the point where the eyes of those who give and those who receive meet"; and that in this moment of exchange "thinking of God separates us from him", "the presence of God in us has as its condition a secret so deep that it is even a secret from us" (Weil, 1977, p. 87). Bob Plant perhaps situates Wittgenstein in this kind of tradition. To bring to light Wittgenstein's affirmation of thinking oneself "wretched" (Wittgenstein 1994, 45; cf. 86) and his denegation of the kind of good conscience in which one believes one's responsibilities have been fulfilled, Plant cites a passage from Dostoyevksy's The Brothers Karamazov - a novel Wittgenstein loved. Alyosha speaks first:

[E]very one of us is responsible for everyone else in every way, and I most of all." Mother could not help smiling at that. She wept and smiled at the same time. "How are you," she said, "most of all responsible for everyone? There are murderers and robbers in the world, and what terrible sin have you committed that you should accuse yourself before everyone else?" "Mother. my dearest heart, my joy, you must realize that everyone is really responsible for everyone and everything. I don't know how to explain it to you, but I feel it so strongly that it hurts. (Dostoyevsky, 1984, p. 339).

I doubt that Dostoyevsky or Wittgenstein would tie the infinitude of the responsibility evoked here - its precluding good conscience - to the contingent fact that Alyosha, unlike Jesus, is a sinner. So I doubt that their attitude resembles the attitudes of Kremer and Mulhall.

Let us now to turn to the other Russian writer whom Wittgenstein loved - in particular, to Tolstoy's tale "The Three Hermits", of which Wittgenstein is reported to have said, "There you have the essence of Christianity!" (King, 1981, p. 72). In the tale, a bishop encounters three hermits living on an island who are devoted to their salvation and mostly remain silent. In response to the Bishop's queries, the hermits say: "We do not know how to serve God. We only serve and support ourselves, servant of God" and recite their only prayer: "Three are ye, three are we, have mercy upon us" (Tolstoy, 1906, p. 97). The bishop speaks to them of the Trinity, and teaches them the Lord's Prayer, no easy task, because of the hermits' age and ignorance. Back on the ship, the bishop sees something bright on the water:

The steersman looked, and let go the helm in terror. "Oh Lord! The hermits are running after us on the water as though it were dry land!"
The passengers, hearing him, jumped up and crowded to the stern. They saw the hermits coming along hand in hand, and the two outer ones beckoning to the ship to stop. All three were gliding upon the water without moving their feet. Before the ship could be stopped, the hermits had reached it, and raising their heads, all three as with one voice, began to say:

"We have forgotten your teaching, servant of God. As long as we kept repeating it we remembered, but when we stopped saying it for a time, a word dropped out, and now it has all gone to pieces. We can remember nothing of it. Teach us again".

The Bishop crossed himself, and leaning over the ship's side, said:

"Your own prayer will reach the Lord, men of God. It is not for me to teach you. Pray for us sinners".

And the Bishop bowed low before the old men; and they turned and went back across the sea. And a light shone until daybreak on the spot where they were lost to sight. (Tolstoy, 1906, pp. 200-201).

Douglas Duhaime argues that the tale exemplifies the value of showing: whereas the hermits "do not attempt to articulate ethical propositions", the Bishop "attempts to teach the Christian ethic to others" - uselessly, given that Christian ethics "cannot be meaningfully articulated" (Duhaime, 2011). Further, the Bishop's most valuable words, his final words, owe less to what they say than to what they do, what they show: at issue is an expression of humility, an action not a proposition. Thus does Duhaime plausibly suggest that the story privileges showing over saying.

Even so, this didactic and non-realistic story seems rather remote from either Conant's account or Diamond's account of the kind of literature that exemplifies showing. Moreover, the story, although rejecting institutionalised repetition, arguably depends on the use of repetition:

The style relies heavily on the device of triplication: Three old men, three reported descriptions of them from three different sources, one of whom is referred to in three different ways (little muzhik, peasant, and fisherman), and so on. Even the syntax reflects this device, with many sentences having a tertiary structure: "What could it be - a boat, or not a boat; a bird, or not a bird; a fish, or not a fish?" The true function of this stylistic device is mnemonic. A triple repetition of story elements on all levels ensures that the lesson transmitted by the story will be well learned. ("'The three hermits': Style and technique,")

Inasmuch as the story appears to use the very thing - teaching through the use of repetition - that it targets, a non-transparency arises that complicates thinking of it simply in terms of showing.

Nor does the story immerse humility in showing, in self-recognition. It is true that at the end of the story, the Bishop, in humility, recognises his lowliness in comparison with the hermits and recognises his earlier failings: His over-emphasis on doctrine and on saying; his condescension to the hermits; the masquerading of his pride as humility when he "thanked God for having sent him to teach and help 
such godly men" (200). And he possibly also recognises his current humility - recognises how imperfect it is, how inferior it is to the humility of the hermits, and how any merit it has is owing to the grace of God, to the encounter with the hermits that God has vouchsafed him. Moreover, in shining like a miraculous light, the humility of the hermits shows itself. But, crucially, their humility does not seem to show itself to the hermits themselves; they do not see this light. And this lack of presence seems to be tied to the miracle. So the story that is often thought to convey Wittgenstein's affirmation of showing testifies to a breach in showing, in presence.

Ascribing to Tolstoy an aristocratic puritanism that is remote from "the common man"; to Tolstoy's humility "a touch of pride"; to Tolstoy's "The Three Hermits" an artistic virtuosity that belies its affirmation of "simplicity of heart and mind" (Hems, 2012, pp. 70-71), the critic John Hems in effect evokes gaps and fissures. At issue is a story that affirms the simplicity of the three hermits yet which could issue from the simplicity that it affirms. LaRocca's account of a "will-based" "disciplined habit of determining one's qualities and lapses" may pertain to the Bishop - and perhaps to the story itself. But I do not see this discipline in the hermits. And the gap here is a breach in showing. The story appears to partake of the simplicity of the hermits, a simplicity that it affirms. Yet in a certain way, this appearance is illusory. These fissures breach the pure showing that we might be inclined to ascribe to the story, opening it to the labour of theory.

Thinking of the story in terms of gaps and fissures removes it from the response that Robert Fogelin evokes when he says that for Wittgenstein "the ethical ideal. cannot be stated directly" but "shows itself in simple tales" - tales such as this one (Fogelin, 1987, p. 100). So the ethical difference between Wittgenstein and Derrida, who insists on such fissures, involves a difference with respect to reading, with respect to text. Jules David Law sees Derrida as "prolonging indefinitely the activity of interpretation" which Wittgenstein wishes to "demystify ... in order to free us from its compulsions" (Law, 1989, p. 146). It is precisely in the face of a story such as "The Three Hermits" that one may find oneself wishing to free oneself from the compulsions of the activity of (endless) interpretation: silent wonder may seem the appropriate response. Even so, I think that the kind of questions that Hems raises with respect to this story - questions which I suspect that Wittgenstein would seek to dismiss - remain pertinent. Thus I am inclined to think that even the kind of text that is most plausibly thought of as resisting endless interpretation seems to prolong the activity of interpretation. In effect, I am allowing saying to breach the purity of showing. But such a breaching may not be an unethical gesture. For the possibility of endless interpretation that Derrida keeps open perhaps itself involves a certain humility, a self-effacement, an effort to resist violence.

My (Derridean) questioning of Wittgenstein's privileging of showing over saying may seem question begging, may seem itself to belong to the very activity of endless interpretation that this privileging seeks to call into question. Yet the fact that some who are sympathetic to the Wittgensteinian account (LaRocca, Mulhall, Kremer) attempt to respond to the kind of concerns at issue may suggest the inevitability of this questioning - something which may in another way be suggested by the fact that the responses to the concerns are, as I have tried to argue, unconvincing. I have also tried to suggest that it is not self-evident that the affirmation of showing can be based on an appeal to the simplicity and force of the kind of literature that moved Wittgenstein. For in effect I have suggested that part of the fascination of this literature may have to do with the way that it seems to invite the kind of questions that Wittgenstein seeks to foreclose. Of course, the force of Wittgenstein's thinking is such that I make no claim that the reservations expressed here constitute anything like a final word. I agree with Ralph E. Shain that the comparisions (in published studies) of Wittgenstein and Derrida are too undeveloped or too inaccurate to yield the hoped for "productive confrontation" (Shain, 2007, p. 130) - a complaint which I think still applies ten years after it was first made. My hope is that the present paper offers some clarification of one of the issues that needs to be addressed in order for the attainment of the understanding that Shain desires.

\section{ENDNOTES}

1 The attitudes to literature at issue here are common. For example, valuing showing over saying informs F. R. Leavis's affirmation of the concreteness of poetry: "Words in poetry invite us, not to 'think about' and judge but to 'feel into' or 'become' - to realize a complex experience that is given in the words" (Leavis, 1962, pp. 212-213). And it informs his affirmation of Thomas Hardy's "quiet presentment of specific fact and concrete circumstance" (in the poem "After a Journey") which evokes "a total situation that, as merely evoked, carries its power and meaning in itself" over Emily Bronte's "declamatory generality - talking about" (in "Cold in the Earth"), her dramatizing herself in a situation "she has clearly not known in actual experience” (Leavis, 1975, p. 129).

\section{REFERENCES}

Bennington, G., \& Derrida, J. (1999). Jacques Derrida. Chicago: University of Chicago.

Cahill, K. (2011). The fate of wonder: Wittgenstein's critique of metaphysics and modernity. New York: Columbia University Press.

Conant, J. (2005). What "ethics" in the Tractatus is not. In D. Z. Phillips \& M. von der Ruhr (Eds.), Religion and Wittgenstein's legacy (pp. 39-88). Aldershot: Ashgate.

Cooper, D. E. (1997). Wittgenstein, Heidegger and humility. Philosophy, 72(279), 105-123.

Derrida, J. (1992a). Force of law: The "mystical foundation of authority". In D. G. Carlson, D. Cornell \& M. Rosenfeld (Eds.), Deconstruction and the possibility of justice (pp. 3-67). New York: Routledge.

Derrida, J. (1992b). Given time. I, Counterfeit money. Chicago: University of Chicago Press.

Diamond, C. (1991). The realistic spirit: Wittgenstein, phi- 
losophy, and the mind. Cambridge, Mass.: MIT Press.

Dostoyevsky, F. (1984). The brothers Karamazov (D. Magarshack, Trans. Vol. 1). Harmondsworth: Penguin.

Duhaime, D. (2011). Reading Wittgenstein reading Tolstoy: Saying and showing in 'The three hermits". Paper presented at the $126^{\text {th }}$ Annual Congress of the Modern Language Association, Los Angeles. https://www.academia. edu/1334740/Reading Wittgenstein Reading TolstoySaying and Showing in The Three Hermits

Engelmann, P. (1968). Letters from Ludwig Wittgenstein. With a memoir. New York: Horizon Press.

Fogelin, R. (1987). Wittgenstein: The arguments of the philosophers (Second ed.). Abingdon: Routledge.

Gaita, R. (1991). Good and evil: an absolute conception. Basingstoke: Macmillan.

Gaita, R. (1999). A common humanity: thinking about love \& truth \& justice. Melbourne: Text Publishing.

Hems, J. (2012). Husserl and/or Wittgenstein. In H. A. Durfee (Ed.), Analytic Philosophy and Phenomenology. The Hague: Martinus Nijhoff.

King, J. (1981). Recollections of Wittgenstein. In R. Rees (Ed.), Ludwig Wittgenstein: Personal recollections (pp. 68-75). Totowa, NJ: Rowman and Littlefield.

Kremer, M. (2001). The purpose of Tractarian nonsense. Nous, 35(1), 39-73.

LaRocca, D. (2013). Note to self: Learn to write autobiographical remarks. In S. Bru, W. Huemer \& D. Steuer (Eds.), Wittgenstein reading (pp. 319-333). Berlin: De Gruyter.

Law, J. D. (1989). Reading with Wittgenstein and Derrida. In R. W. Dasenbrock (Ed.), Redrawing the lines: Analytic philosophy, deconstruction, and literary theory. Minneapolis: University of Minnesota Press.

Leavis, F. R. (1962). The common pursit. Harmondsworth: Penguin.

Leavis, F. R. (1975). The living principle: "English" as a discipline of thought. London: Chatto \& Windus.

Lewis, C. S. (1996). The essential C. S. Lewis (L. W. Dorsett Ed.). New York: Simon Schuster.

Lindroos-Hovinheimo, S. (2012). Justice and the ethics of legal interpretation. Oxford: Routledge.

Malcolm, N. (2001). Wittgenstein: a memoir. London: Ox- ford University Press.

McGuinness, B. (1988). Wittgenstein: A life: Young Ludwig, 1889-1921 (Vol. 1). Berkeley: University of California Press.

Mulhall, S. (2016). The great riddle: Wittgenstein and nonsense, theology and philosophy. Oxford: Oxford University Press.

Pickford, H. W. (2016). Thinking with Tolstoy and Wittgenstein: Expression, emotion, and art (Kindle Edition ed.). Evanston, Illinois: Northwestern University Press.

Plant, B. (2004). The wretchedness of belief: Wittgenstein on guilt, religion, and recompense. Journal of Religious Ethics, 32(3), 449-476.

Proust, M. (2000). Time regained (A. Mayor \& T. Kilmartin, Trans.). London: Vintage.

Shain, R. E. (2007). Derrida and Wittgenstein: Points of opposition. Journal of French Philosophy, 17(2), 130-152.

Shields, P. R. (1993). Logic and sin in the writings of Ludwig Wittgenstein. Chicago: University of Chicago Press.

Staten, H. (1984). Wittgenstein and Derrida. Lincoln: University of Nebraska Press.

'The three hermits': Style and technique. Comprehensive Guide to Short Stories, Critical Edition, eNotes. com(Charles E. May, Editor). <http://www.enotes.com/ topics/three-hermits/in-depth\#in-depth-style-and-technique $>$

Tolstoy, L. (1906). Twenty-three tales (L. Maude \& A. Maude, Trans.). Oxford: Oxfored University Press.

Weil, S. (1977). Waiting on God: Lectures and essays (E. Crauford, Trans.). London: Fount.

Wittgenstein, L. (1922). Tractatus logic-philosophicus (C. K. Ogden, Trans.). London: Kegan Paul, Trench, Trubner.

Wittgenstein, L. (1974). Letters to Russell, Keynes and Moore (G. H. Von Wright \& G. E. M. Anscombe Eds.). Oxford: Blackwell.

Wittgenstein, L. (1980). Culture and Value (P. Winch, Trans. G. H. Von Wright Ed.). Oxford: Basil Blackwell.

Wittgenstein, L. (2003). Ludwig Wittgenstein: Public and private occasions. Lanham: Rowman \& Littlefield. 